\title{
The Invalidity of Foreign Currency Loans in the Hungarian Judicial Practice
}

\author{
Péter Bálint Király*
}

\footnotetext{
* JUDr. Péter Bálint Király, PhD student, Department of Administrative and Financial Law, Faculty of Law, Széchenyi István University. (e-mail: kiralypeterbalint@gmail.com)
}

\begin{abstract}
After the economic crisis, a large part of the Hungarian population could not repay the suddenly increased instalments of their foreign currency loans. In lawsuits concerning the invalidity of these foreign currency loans, the different courts interpreted the provisions of the law differently, so the Curia (the highest judicial authority of Hungary) - fulfilling its constitutional duty - considered it necessary to unify the judicial practice. For this purpose, several Uniformity Decision were adopted. In this study I will briefly summarize the content of three Uniformity Decisions, namely, Decision No. 6/2013 PJE, No. 2/2014 PJE and No. 1/2016 PJE.
\end{abstract}

Keywords: foreign currency loan; invalidity of contracts; exchange rate spreads

\section{Introduction}

The subject of my paper is the evaluation of the foreign currency loan in the Hungarian judicial practice, which have been one of the major challenges for both the legislature and the courts after the economic crisis, as a large part of the Hungarian population had such loans and could not repay the suddenly increased instalments. In lawsuits concerning the invalidity of these foreign currency loans, the different courts interpreted the provisions of the law differently, so the Curia (the highest judicial authority of Hungary) - fulfilling its constitutional duty - considered it necessary to unify the judicial practice. For this purpose, several Uniformity Decision were adopted. "The Curia renders uniformity decisions in cases raising issues of theoretical importance in order to ensure the uniform application of law within the Hungarian judiciary. Such decisions are binding on all Hungarian courts." In this study I will briefly summarize the content of three Uniformity Decisions, namely, Decision No. 6/2013 PJE, No. 2/2014 PJE and No. 1/2016 PJE.

\section{Uniformity Decision No. 6/2013 PJE of the Curia}

In this Uniformity Decision the Curia stated that foreign currency loan contracts are those in which the debtor is in debt in a foreign currency, but the loan is paid and repaid in the domestic currency (in this case HUF). At the time of the conclusion of the contracts, there 
was no law that would have established a ceiling on the risk of the debtor or would generally have prohibited the risk of a change in the exchange rate.

In the view of the Curia, the assumption that the amount of repayment of foreign currency loans in the future could not be accurately determined at the time of the conclusion of the contract is considered false. "The debtor's debt [...] is clearly stated at the time of the conclusion of the contract: it is the amount determined in the calculation currencies. The fact that, at the time of the conclusion of the contract, it is not possible to tell how much payment currency is to be paid by the debtor to fulfil their contractual obligation, necessarily arises from the difference between calculation currency (foreign currency) and the payment currency (HUF). However, this does not affect the clear definition of the obligation." It is also considered a concrete definition of the amount of debt, if the amount paid out loan and the instalments are not quantified, but the contract clearly contains the calculation method.

Act CCXXXVII of 2013 on Credit Institutions and Financial Enterprises (hereinafter referred to as Hpt.) requires the financial institution to inform the debtor about the possibility that the exchange rate might change in the future, and what effects it can have on the debtor's obligations. However, the obligation to provide information did not, of course, cover the degree and direction of exchange rate change. Creditors did not have to declare the expected exchange rate of the Forint during the contract period as this is unforeseeable at the conclusion of the contract. Therefore, such a commitment could not be fulfilled. The unforeseen, unilateral shift in contractual burdens after the conclusion of the contract cannot be considered a cause of invalidity, because the reason for the invalidity must exist at the conclusion of the contract.

The Curia also found that foreign currency loan does not conflict with the law because of its aforementioned properties. This does not mean, of course, that a particular contract or contractual terms cannot be invalid for any other reason (e.g. unfairness). It only means that the foreign currency loan as a type of contract does not conflict with the law. Deciding whether or not each contract is invalid or not is only possible in specific cases.

A foreign currency-based loan agreement cannot be regarded as an immoral contract. According to the Hungarian judicial practice, a contract is considered immoral if the society has a negative value judgment on it. Foreign currency based loan agreements were not condemned by society at the time of their conclusion. Consumers took the risk of exchange rate fluctuations because they could have received a more favourable interest rate on a foreign currency based loan than for HUF-based loans. The unfavourable development of the circumstances after the conclusion of the contract, cannot justify the invalidity of the contract.

A foreign currency loan agreement cannot be regarded as a usury contract. According to the Hungarian Civil Code a contract is deemed to be a usury if the contractor has made a remarkably disproportionate advantage when exploiting the position of the other party at the conclusion of the contract. It follows from the nature of the blanket contracts used by financial institutions that the financial institution cannot take the financial situation of the consumer into consideration. The same terms of contract were used with consumers in a bad financial situation as with those who were in good financial standing. We cannot therefore say that the banks have taken advantage of the economic situation of the 
consumers. The Curia also explained that the financial institutions did not receive wrongful benefit with this practice, because only the Forint equivalent of the foreign currency was repaid by the debtors at the time of repayment. The amount of debt remained the same in the foreign currency, even though its equivalent in Forint has changed. ${ }^{2}$

\section{Uniformity Decision No. 2/2014 PJE of the Curia}

According to this Uniformity Decision, a contractual provision allowing unilateral contract modification is unfair if it does not comply with the following principles: clear and comprehensible wording, item-by-item definition, objectivity, factuality and proportionality, transparency, termination, and symmetry principles (hereinafter referred to as seven principles).

In addition, the Curia has stated that, in foreign currency loans, a clause stipulating that the consumer will bear unlimited liability for exchange rate risk is considered to be the primary object of the contract. Therefore, its invalidity can only be examined and ascertained, "if the contents of the contract at the time of its conclusion - taking account of the text of the contract and the information provided by the financial institution - were not clear to a generally well-informed, reasonably attentive and circumspect average consumer", and therefore, they could reasonably believe that the exchange rate risk was not real.

The principle of clear and comprehensible wording has only been incorporated into the Civil Code by an amendment in 2009. The question therefore arises whether the principle should be applied before the entry into force of the amendment. By joining the European Union, Hungary is also obliged to interpret the provisions of the national law in accordance with EU law if it does not lead to contra legem interpretation. The provision of Directive No. 93/13 EEC - which states that the unfairness of a condition determining the main service is met, the principle of clear and comprehensible wording cannot be investigated - is not in conflict with the Hungarian law. Therefore, this principle must be taken into account when judging contracts concluded prior to the modification of the Civil Code.

According to Article 203 of the Hpt. "the financial institution shall disclose to the customer the risk of the contractual transaction, the acknowledgment of which is certified by the signature of the client". In determining the unfairness of a contract term, the court must take into account all the circumstances leading to the conclusion of the contract, including information provided by the financial institution to the consumer. If, on the basis of all these relevant circumstances, "a generally well-informed, reasonably attentive and circumspect average consumer" was able to recognize that the risk of exchange rate fluctuations would be borne without restriction, the unfairness of that condition could not be stated. In connection with this, the Curia establishes the presumption that if the customer has received the information required by law and has signed the declaration, it must be regarded as the wording of the contract was clear and comprehensible. The bank must demonstrate that the customer has been informed in this accordingly. The contract is considered to be unfair if the fact that it was not clear and comprehensible for the consumer 
that he or she bears the risk exchange rate fluctuation is attributable to the financial institution. This must be proved by the consumer.

The debtors must therefore be placed in a situation to be able to measure their contractual obligations. This means that the contract must indicate the possible evolution of the contractual burdens. It must contain a list of reasons which must clearly disclose the mechanism and possible extent of the change in the obligation arising from the change of circumstances, that is to say, if the condition clearly and comprehensibly stipulates how and to what extent the debtor's existing debt is changed by the changes in the circumstances determined in the contract. The solution is not appropriate in this context if the contract merely lists the circumstances giving rise to a contract modification. Without adequate explanation, these do not comply with the principle of transparency. The terms for unilateral amendment of the contract is not unfair if it ensures the possibility of inspecting the compliance with the seven principles and the contractual provisions, and that the consumer may take remedy against the financial institution.

The Curia considered the practice of financial institutions to be unfair as the amount paid was calculated on the basis of their own purchase and repayment details based on their own selling price, because it constitutes an unjustified and unilateral disadvantage to the consumer with the breach of the requirement of good faith and fairness. The selling rate is always bigger than buying, which means that on the side of the financial institutions this practice generates profit while on the debtor's side it creates expense. This is an unreasonable cost against which there is no direct financial service by the financial institution. In case of foreign currency loans, when determining the repayment instalment, no real exchange of money is made, but only the amount of the debt is calculated at the exchange rate at the time of completion. "Thus, the exchange rates in foreign currency loans don't represent a real, and direct currency exchange service for the customer." This mechanism of pricing is also unfair because it does not meet the requirement of clear and comprehensible wording, because even in case of a grammatically clear wording, the consumer cannot anticipate the amount of debt they have to pay to fulfil their obligations, as the economic reasons behind the different exchange rates are not clear and transparent to the average consumer. According to the decision of the Court of Justice of the European Union, the unfair terms of contract shall be replaced with the dispositive provision of the Civil Code, ${ }^{3}$ according to which "the amount specified in other currencies shall be converted at the exchange rate prevailing at the time and place of payment". ${ }^{\prime \prime}$ The Curia therefore requires that the purchase and sale rates in the contracts be replaced by the Hungarian Central Bank's official exchange rate. ${ }^{5}$

\section{Uniformity Decision No. 1/2016 PJE of the Curia}

According to Act CXII of 1996 a consumer loan agreement is invalid if (among other reasons) it does not include the subject of the contract, the number of instalments, the amount of the repayment instalments, and the repayment dates. The Curia has found that according to the Hpt., the foreign currency loan contract does not qualify as null and void, if it contains the amount of the loan to be disbursed in HUF, and the contract also states 
that the financial institution keeps a record about the amount of loan in a foreign currency, furthermore it specifies in a predictable manner the numbers, amounts and payment dates of the instalments to be paid. Thus, the contract is valid if it is clearly established that the parties have concluded a foreign exchange contract, and their intention was therefore to register and determine the loan, its interest and its contributions in foreign currency, but it was intended to pay in HUF. The Curia also states that "if the amount of the loan is given in both currencies on the date of the conclusion of the contract, one of the two amounts is only informative, depending on whether the given contract considers the foreign currency or HUF as the starting point".

An important condition in each case is that the contract includes the method by which the loan amount in the payment currency (i.e. in HUF) can be derived from the calculation currency (i.e. in foreign currency). However, it does not impact the validity of the contract whether it precisely states the date of conversion, because unless otherwise provided by the parties, the conversion date is by ipso iure the day of disbursement. If the contract or the general terms and conditions of the contract together meet these criteria, then the financial institution's unilateral legal declaration (e.g. reimbursement notification, loan repayment plan, loan repayment schedule) is to be considered as information provided to the consumer by the financial institution. "This information is not considered as unilateral declaration of intent that intends to produce legal effects, therefore it cannot be evaluated as a shaping right resulting either in the creation of a contract or for modifying or terminating it. Therefore, the non-delivery of the notice or its content contrary to the contract does not affect the creation or validity of the contract." The ineffectiveness of the contract cannot be established either because of the absence of a reference currency conversion rate, because the legislator stated that the relevant exchange rate is the official exchange rate of the Hungarian Central Bank. ${ }^{6}$

\section{Summary and Comments on the Uniformity Decisions of the Curia}

First, I would like to point out the reasons of an individual case, the so-called Kásler-case, according to which the financial institutions gain additional revenue by using the spread between buying and selling rates in their contract. However, with this the financial institution does not provide real money exchange service, but only the amount of the debt is calculated at the exchange rate at the time of completion. So the financial institution does not provide any service for the customer, and yet they gain additional profit because of this method. Therefore, these contract terms are unfair and void. This is in line with 2/2014 PJE, according to which the selling price is always higher than the purchase price. On the side of financial institutions this practice generates revenue while on the debtor's side it creates expenses. ${ }^{7}$ However, this reasoning contrasts with the decision of the Uniformity Decision No. 6/2013 of the Curia, which stated that the risk of exchange rate change is borne by the consumer while the position of the creditor is not affected by this. Even though the debtors have to repay more in HUF compared to the amount that was disbursed to them, but as the amount of loan is registered in a foreign currency according 
to these contracts, the foreign currency equivalent of that amount of HUF the debtors repaid remains the same. So the amount of money the financial institution lends and the amount the debtors repay is the same in the foreign currency. That is why the financial institution does not gain any additional revenue because of this method. ${ }^{8}$

The other contradiction I would like to draw attention to is also in connection with the exchange rate spread. In relation to the exchange rate spread, the Curia states in the Uniformity Decision No 2/2014 PJE that: "This mechanism of pricing does not meet the requirement of clear and comprehensible wording, because even in the case of a grammatically clear wording, the consumer cannot anticipate the amount of debt they have to pay to fulfil their obligations." "This is contrary to Uniformity Decision No. 6/2013 PJE, which stated that in any foreign currency loan the amount of the debt can be clearly determined at the time of the conclusion of the contract: it is the amount determined in the calculation currencies. "The fact that, at the time of the conclusion of the contract, it is not possible to tell how much payment currency is to be paid by the debtor to fulfil their contractual obligation, necessarily arises from the difference between calculation currency (foreign currency) and the payment currency (HUF). However, this does not affect the clear definition of the obligation." In addition, the unforeseeable unilateral shift in contractual burdens after the conclusion of the contract cannot be considered invalidity reasons, because in order to establish invalidity, the reason for invalidity must exist at the time of the conclusion of the contract. ${ }^{10}$

The problem of the exchange spreads applied by financial institutions was finally settled by the legislator by establishing an irrefutable presumption, that the application of different purchase and sale rates provided by an individually non-discussed, or general contract term is unfair, therefore void and null. Due to their invalidity, the buying and selling rates are dropped out of the contract and are replaced by the Hungarian Central Bank's official exchange rate. ${ }^{11}$ The financial institutions are subject to clearing obligations, with regard to overpayments caused by the application of the exchange rate spreads. ${ }^{12} \mathrm{With}$ these statutory provisions referenced in the Uniformity Decision No. 1/2016 PJE the Curia stated that the invalidity of the contract cannot be established because of the absence of an exchange rate.

All in all, it can be concluded that the Uniformity decisions of the Curia were not completely consistent. Finally, however, the legislator has arranged - for the past and the future alike - the applicable exchange rate, and the amount of interest rates, costs and fees. "Because these calculations are based on a legal act, these conditions necessarily constitute a fair individually non-discussed general contract term, and contractual content. In addition, they cannot be considered to be in conflict with the legislation." 13 These contracts should also be measured in the light of these legal acts, when the courts decide whether the content of contracts meet the obligations required by the Hpt. as the validity requirements of foreign currency loan. 


\section{References}

1 www.lb.hu/en/uniformity-decisions (accessed 01 March 2017).

2 Uniformity Decision No. 6/2013 PJE, www.lb.hu/en/uniformity-decisions (accessed 01 March 2017).

3 Uniformity Decision No. 2/2014 PJE, www.lb.hu/en/uniformity-decisions (accessed 01 March 2017).

4 Civil Code of Hungary (Act V of 2013).

5 Uniformity Decision No. 2/2014 PJE, www.lb.hu/en/uniformity-decisions (accessed 01 March 2017).

6 Uniformity Decision No. 1/2016 PJE, www.lb.hu/en/uniformity-decisions (accessed 01 March 2017).

7 Uniformity Decision No. 2/2014 PJE, www.lb.hu/en/uniformity-decisions (accessed 01 March 2017).

8 Uniformity Decision No. 6/2013 PJE, www.lb.hu/en/uniformity-decisions (accessed 01 March 2017).

9 Uniformity Decision No. 2/2014 PJE, www.lb.hu/en/uniformity-decisions (accessed 01 March 2017).

10 Uniformity Decision No. 6/2013 PJE, www.lb.hu/en/uniformity-decisions (accessed 01 March 2017).

11 Act XXXVIII of 2014, Section 3.

12 Act XL of 2014, Section 3.

13 Uniformity Decision No. 1/2016 PJE, www.lb.hu/en/uniformity-decisions (accessed 01 March 2017). 